\title{
Hvað skýrir viðhorf fólks til auglýsinga?
}

\author{
Auður Hermannsdóttir ${ }^{1}$
}

\begin{abstract}
Ágrip
Viðhorf fólks til auglýsinga almennt hefur áhrif á mat pess á einstökum auglýsingum. Viðhorf og mat fólks á einstaka auglýsingum hefur svo m.a. áhrif á kaupætlun og á viðhorf til pess vörumerkis sem um ræðir. Almennt viðhorf fólks til auglýsinga getur pví gefið verðmætar upplýsingar um hversu áhrifaríkar einstaka auglýsingar eru. Markmið rannsóknarinnar var að kanna hvert viðhorf íslenskra neytenda er til auglýsinga almennt ásamt pví að kanna hvaða pættir skýra viðhorfið. Jafnframt var markmiðið að kanna hvort viðhorf til auglýsinga væri ólíkt eftir lýðfræðibreytum. Alls svöruðu 550 einstaklingar netkönnun um ýmislegt sem tengist auglýsingum. Niðurstöður sýna að viðhorf íslenskra neytenda til auglýsinga er nokkuð jákvætt og skýrist fyrst og fremst af upplýsingagildi og gagnsemi auglýsinga. Eftir pví sem neytendur eru eldri pví neikvæðara er viðhorf peirra til auglýsinga.
\end{abstract}

\begin{abstract}
People's attitude towards advertising in general has an influence on people's perceptions on specific ads. People's attitude towards specific ads has among others influence on purchase intentions and on brand attitude. Therefore general attitude towards advertising can give valuable information on how effective advertising may be. The purpose of the study was to explore the attitude of Icelandic consumers towards advertising in general and to find out what factors explain the attitude. Also, the purpose was to find out whether the attitude depended on people's demographic profile. Total of 550 individuals participated by answering an online questionnaire on various things regarding advertising. The findings reveal that Icelandic consumers are rather positive regarding advertising in general and their attitude can mostly be explained by how informative and useful they find ads. The older the consumers are, the more negative attitude they have towards advertising.
\end{abstract}

JEL flokkun: C38, M37

Lykilhugtök: Auglýsingar, viðhorf, neytendur

${ }^{1}$ Höfundur er aðjúnkt við Viðskiptafræðideild Háskóla Íslands. Auði Hafpórsdóttur eru veittar sérstakar pakkir fyrir pátttöku við gagnaöflun og pýðingu mælitækis. Höfundur vill jafnframt pakka tveimur ónafngreindum ritrýnum fyrir gagnlegar ábendingar. 


\section{Inngangur}

Tilgangur auglýsinga getur verið margpættur og ólíkur frá einni auglýsingu til annarrar. Í sumum tilfellum getur tilgangurinn verið að upplýsa neytendur um eiginleika tiltekinnar vöru eða pjónustu, í öðrum tilfellum getur tilgangurinn verið að fá neytendur til að prófa nýja vöru eða pjónustu. Stundum er tilgangurinn að minna á tiltekið vörumerki og par með auka vörumerkjavitund og í sumum tilfellum er verið að kynna verðlækkanir eða tilboð. Lokamarkmiðið er pó ávallt að pað eigi sér stað einhver viðskipti, p.e. að hafa áhrif á hegðun neytandans pannig að hann kaupi vöru eða pjónustu auglýsandans.

Auglýsingar hafa verið gagnrýndar töluvert í gegnum tíðina og eru af sumum taldar geta haft mikil og neikvæð áhrif á neytendur. Ein algengasta gagnrýnin er sú að auglýsingar séu blekkjandi og gefi ekki rétta mynd af pví sem verið er að auglýsa hverju sinni (Andrews, 1989; Mukherji, 2009). Sumir telja að vald peirra sé slíkt að með peim sé hægt að fá neytendur til að framkvæma hluti gegn vilja sínum (Andrews, 1989). Jafnframt hefur pví verið haldið fram að með brögðum séu höfð áhrif á grunngildi neytenda (Andrews, 1989) og að auglýsingar ýti undir ýmis neikvæð gildi eins og kynjamisrétti (Monk-Turner, Kouts, Parris og Webb, 2007; Mukherji, 2009) og ofbeldi (José Martínez, Dolores Prieto og Farfán, 2006; Mukherji, 2009). Auglýsingar hafa einnig verið sagðar gera lítið úr greind neytenda og sannfæra pá um að kaupa hluti sem peir ættu ekki að kaupa, auk pess sem pær hafa verið sagðar leiða til hærra verðs á vörum og pjónustu (Andrews, 1989).

Viðhorf fólks til auglýsinga almennt hefur áhrif á mat pess á einstökum auglýsingum sem birtast peim (Mackenzie og Lutz, 1989; O’Donohoe, 2001). Viðhorf og mat fólks á einstaka auglýsingum hefur svo áhrif á hvernig pað bregst við auglýsingunum, t.d. hvort auglýsingarnar auki líkur á kaupum (Mehta, 2000) og hvert viðhorfið verður til vörumerkisins sem um ræðir (Mackenzie og Lutz, 1989). Almennt viðhorf fólks til auglýsinga getur pví gefið verðmætar upplýsingar um hversu áhrifaríkar einstaka auglýsingar eru (Calfee og Ringold, 1988; Pollay og Mittal, 1993).

Markmið rannsóknarinnar er að kanna hvert viðhorf íslenskra neytenda er til auglýsinga almennt ásamt pví að kanna hvað skýrir viðhorfið. Jafnframt er markmiðið að kanna hvort viðhorf til auglýsinga almennt séu ólík eftir lýðfræðibreytum. Rannsóknarspurningarnar sem lagðar eru til grundvallar eru:

a) Hvaða pættir skýra viðhorf fólks til auglýsinga?

b) Er munur á viðhorfi til auglýsinga eftir lýðfræðibreytum?

Rannsóknin hefur bæði fræðilegt og hagnýtt gildi. Niðurstöður hennar veita fræðimönnum og fagfólki á sviðinu upplýsingar um almennt viðhorf íslenskra neytenda, en mikill áhugi hefur verið meðal fræðimanna á að kanna viðhorf ólíkra pjóða til auglýsinga (sjá t.d. Ashill og Yavas, 2005; Bush, Smith og Martin, 1999; Petroviki og Marinov, 2007; Shah, Chen og Chauhan, 2011; Usman, Ilyas, Hussain og Quareshi, 2010). Pó parf að hafa í huga að um hentugleikaúrtak er að ræða og pví ber 
að líta á niðurstöðurnar sem ákveðna vísbendingu um viðhorfið, en ekki er hægt að fullyrða аð viðhorf úrtaksins endurspegli viðhorf íslenskra neytenda almennt. Niðurstöðurnar veita jafnframt verðmætar upplýsingar um hvaða pætti mikilvægast er að leggja áherslu á til að auka líkurnar á pví að viðhorf til auglýsinga sé jákvætt. Einnig er mikilvægt að fá vitneskju um viðhorf einstakra hópa til ýmissa pátta er varða auglýsingar.

Byrjað verður á að gefa yfirlit yfir fyrri rannsóknir á sviðinu. Par verður helst fjallað um rannsóknir á almennu viðhorfi til auglýsinga, mat fólks á trúverðugleika auglýsinga og mat fólks á áhrifum og ávinningi auglýsinga. Í kjölfarið verður gerð grein fyrir peirri aðferðafræði sem beitt var við rannsóknina og síðan farið yfir niðurstöðurnar. Að lokum verður almenn umræða um niðurstöðurnar og pær settar í samhengi við fyrri rannsóknir á viðfangsefninu.

\section{Yfirlit yfir fyrri rannsóknir}

Almennt viðhorf til auglýsinga byggist á uppsafnaðri reynslu fólks af auglýsingum. Pví er um lærða tilhneigingu að ræða til að bregðast með fyrirfram ákveðnum hætti við auglýsingum (Ashill og Yavas, 2005; O’Donouhou, 2001). Almennt viðhorf byggir pví á tilfinningalegu mati en ekki vitsmunalegu mati eða hegðunarlegum viðbrögðum við auglýsingum (Mackenzie og Lutz, 1989).

Almennt viðhorf fólks til auglýsinga skiptir auglýsendur máli pví slíkt mat hefur áhrif á mat á einstaka auglýsingum (O’Donohoe, 2001; Mackenzie og Lutz, 1989). Viðhorfið til einstakra auglýsinga hefur svo áhrif á hvort fólk tekur eftir peim, man eftir peim og pví sem verið er að auglýsa og hvort líkur séu á að auglýsingin leiði til kaupa (Fam, 2008; Mehta, 2000; Prendergast, Liu og Poon, 2009). Almennt viðhorf fólks til auglýsinga hefur oft reynst vera fremur nálægt hlutleysi (p.e. nálægt premur á fimm punkta kvarða), en yfirleitt hallast viðhorfið fremur í jákvæða átt en neikvæða (sjá t.d. Beard, 2003; Petroviki og Marinov, 2007), pótt vissulega séu dæmi um rannsóknir sem sýna að viðhorfið hallist fremur í átt að neikvæðni (sjá t.d. Bush o.fl., 1999).

Rannsóknir hafa sýnt misvísandi niðurstöður um viðhorf fólks eftir lýðfræðibreytum, t.d. eftir kyni (sjá t.d. Mehta, 2000; Shavitt, Lowery og Haefner, 1998; Wolin og Korgaonkar, 2003), en einnig pegar kemur að aldri par sem yngra fólk reynist alla jafna jákvæðara í garð auglýsinga en pað eldra (Petroviki og Marinov, 2007; Shavitt o.fl., 1998). Líkt og Shavitt o.fl. (1998) benda á kann pað að skýrast af eðli peirra auglýsinga sem beint er að ólíkum aldurshópum. Jafnframt kann ástæðan að vera sú að auglýsingar beinast sjaldnar að eldra fólki en pví yngra (Carrigan og Szmigin, 1999) og pví getur verið að auglýsingar höfði sjaldnar til peirra eldri.

Fólk af ólíkri menningu getur haft ólíkt viðhorf og brugðist á ólíkan hátt við auglýsingum (Fam, 2008; Jozsa, Insch, Kristjanous og Fam, 2010). Jafnframt getur viðhorfið verið ólíkt eftir pví hvers konar miðlar eru notaðir til að auglýsa (Prendergast o.fl., 2009).

Mat fólks á trúverðugleika auglýsinga hefur reynst segja til um almennt viðhorf fólks til auglýsinga (Ashill og Yavas, 2005). Рað hversu trúverðugar einstaka auglýsingar eru hefur jafnframt áhrif á viðhorf til pess vörumerkis sem um ræðir og á kaupætlun (Mackenzie og Lutz, 1989). Neikvætt viðhorf getur pannig hindrað 
árangur auglýsinga sem tæki í boðmiðlun fyrirtækja (Beard, 2003; Calfee og Ringold, 1988) og pví er afar mikilvægt fyrir auglýsendur að útbúa auglýsingar sem eru trúverðugar (Ashill og Yavas, 2005).

Prátt fyrir fremur jákvætt viðhorf til auglýsinga hafa rannsóknir yfirleitt sýnt að fólk er tortryggið í garð pess sem par kemur fram (Ford, Smith og Swasy, 1990; Petroviki og Marinov, 2007; Shah o.fl., 2011). Fólki finnst auglýsingar oft blekkja með pví að sýna ekki réttu myndina af peirri vöru eða pjónustu sem verið er að auglýsa (Mehta, 2000; Muehling, 1987) og lítur pví almennt svo á að auglýsingar gefi ekki áreiðanlegar upplýsingar um vöru og pjónustu (Beard, 2003; Prendergast o.fl., 2009). Trúverðugleiki auglýsinga fer pó að vissu leyti eftir peim vöruflokki eða tegund pjónustu sem verið er að auglýsa. T.d. hafa auglýsingar um vörur eða pjónustu í tengslum við megrun og pyngdartap verið gagnrýndar vegna blekkjandi framsetningar (Prendergast o.fl., 2009).

Sumir rannsakendur hafa talið að neikvætt viðhorf til auglýsinga og lítill trúverðugleiki geti orðið til pess að hertari lagaumgjörð verði sett um auglýsingar sem gæti haft neikvæð áhrif á auglýsendur (sjá t.d. Beard, 2003). Calfee og Ringold (1994) benda pó á að tortryggni fólks í garð auglýsinga hafi verið mikil og stöðug í gegnum tíðina prátt fyrir aukna og hertari lagasetningu í pessum efnum. Pví má draga í efa að lagasetning sé til pess fallin að auka trúverðugleika auglýsinga.

Ashill og Yavas (2005) leggja áherslu á að til að auka trúverðugleika auglýsinga purfi auglýsendur að forðast ýkjur um gæði og kosti pess sem verið er að auglýsa. Jafnframt ætti að leggja meiri áherslu á ápreifanlega eiginleika fremur en skynjaða óápreifanlega eiginleika (Ashill og Yavas, 2005) og pegar mögulegt er ætti að draga fram eiginleika sem neytendur geta sannreynt fyrir kaup (Ford o.fl., 1990). Jafnframt parf að huga að pví hvaða miðill er notaður til að koma auglýsingu á framfæri. Ef neytendur telja miðilinn ótrúverðugan trúir pað síður auglýsingunni (Prendergast o.fl., 2009).

Rannsóknir hafa ýmist sýnt að fólk telji auglýsingar hafa jákvæð eða neikvæð áhrif á efnahagslífið. Jákvæðu áhrifin felast pá einna helst í pví mati að auglýsingar örvi hagkerfið og hafi jákvæð áhrif á lífskjör (Coulter, Zaltman og Coulter, 2001), en neikvæðu áhrifin felast einna helst í pví mati að auglýsingar hækki verð á vöru og pjónustu (Beard, 2003; Shavitt o.fl., 1998; Usman o.fl., 2010). Áhrifin á kauphegðun eru að sumra mati töluverð par sem fólk virðist telja að auglýsingar geti leitt til pess að fólk kaupi hluti sem pað ætti ekki að kaupa og í raun vill ekki kaupa (Calfee og Ringold, 1994; Muehling, 1987).

Prátt fyrir að trúverðugleiki auglýsinga sé almennt ekki mikill hefur pað sýnt sig að almennt pyki fólki pær upplýsandi og gagnlegar við að koma á framfæri hvað sé í boði á hverjum stað og að kynna fólki nýja hluti sem pað að öðrum kosti myndi ekki vita af (Mehta, 2000; Shavitt o.fl., 1998). Hefur pað verið talið einn af helstu kostum auglýsinga að mati neytenda (Coulter o.fl., 2001). Jafnframt hafa rannsóknir sýnt að auglýsingar hafa nokkurt skemmtanagildi í huga neytenda (Fam, 2008; Shavitt o.fl., 1998). 


\section{Aðferð}

Hér verður gerð grein fyrir aðferðafræði rannsóknarinnar, pátttakendum og mælitæki lýst ásamt pví að framkvæmdin verður útlistuð.

\subsection{Dátttakendur}

Notast var við rafrænt snjóboltaúrtak. Tengill á rafræna könnun var sendur á fólk sem valið var af hentugleika par sem óskað var eftir pátttöku, en jafnframt var óskað eftir pví að fólk sendi könnunina áfram á aðra. Alls bárust 550 svör. Kynjahlutfall var nokkuð ójafnt eins og sjá má í töflu 1 . Almennt virðast konur tilbúnari til að taka pátt í að svara könnunum sem pessari, enda hefur pað sýnt sig í rannsóknum að konur eru oft í töluverðum meirihluta pegar notast er við hentugleikaúrtak eins og hér er gert (sjá t.d. Ashill og Yavas, 2005; Beard, 2003). Pátttakendur voru spurðir hvort peir störfuðu eða hefðu starfað í tengslum við auglýsingar, enda var talið að slíkt gæti haft áhrif á viðhorf fólks.

\subsection{Mælitæki}

Mælitæki rannsóknarinnar var pýðing á mælitæki sem notað var í rannsókn Pollay og Mittal (1993). Mælitækinu er ætlað að mæla viðhorf fólks til auglýsinga almennt, en grein peirra Pollay og Mittal (1993) er talin ein af helstu tímamótagreinum á sviði slíkra rannsókna (Coulter o.fl., 2001). Mælitækið byggir á fullyrðingum sem pátttakendur eru beðnir um að taka afstöðu til á fimm punkta kvarða par sem 1 táknaði að pátttakendur væru mjög ósammála fullyrðingunni og 5 táknaði að peir væru mjög sammála fullyrðingunni.

Í rannsókn Pollay og Mittal (1993) voru spurningalistar lagðir fyrir tvo ólíka hópa, annars vegar háskólanemendur og hins vegar fullorðið fólk sem sá um heimili (heads of households). Spurningalistarnir voru líkir en ekki nákvæmlega eins. Sá listi sem lagður var fyrir háskólanemendurna var örlítið ítarlegri. Í pessari rannsókn var notast við ítarlegri listann, p.e. listann sem lagður var fyrir háskólanemendurna. Pollay og Mittal framkvæmdu páttagreiningu á svörum háskólanemendanna sem skilaði sex pátta lausn.

Margar fullyrðinganna hafa verið notaðar í svipuðum rannsóknum á viðhorfi fólks til auglýsinga (sjá t.d. Andrews, 1989; Ashill og Yavas, 2005; Beard, 2003; Mehta, 2000; Muehling, 1987; Petroviki og Marinov, 2007; Shah o.fl., 2011; Usman o.fl., 2010). Almennt viðhorf til auglýsinga var mælt með spurningunni: „Almennt séð, líkar pér auglýsingar illa eða vel?“" Svarkostir voru eins og áður á 5 punkta kvarða par sem 1 táknaði að fólki líkaði mjög illa við auglýsingar og 5 táknaði að fólki líkaði mjög vel við auglýsingar.

Tafla 1. Bakgrunnsupplýsingar um pátttakendur

\begin{tabular}{lrlrlr}
\hline & \multirow{2}{*}{ Kyn } & \multicolumn{2}{c}{ Aldur } & \multicolumn{2}{c}{$\begin{array}{c}\text { Hafa starfað við } \\
\text { auglýsingar }\end{array}$} \\
\hline Konur & $68,70 \%$ & 25 ára eða yngri & $22,0 \%$ & Já & $15,90 \%$ \\
Karlar & $31,30 \%$ & 26 til 35 ára & $40,4 \%$ & Nei & $84,10 \%$ \\
& & 36 til 45 ára & $17,9 \%$ & & \\
& & 46 til 55 ára & $10,2 \%$ & \\
& & 56 ára eða eldri & $9,5 \%$ & \\
\hline
\end{tabular}




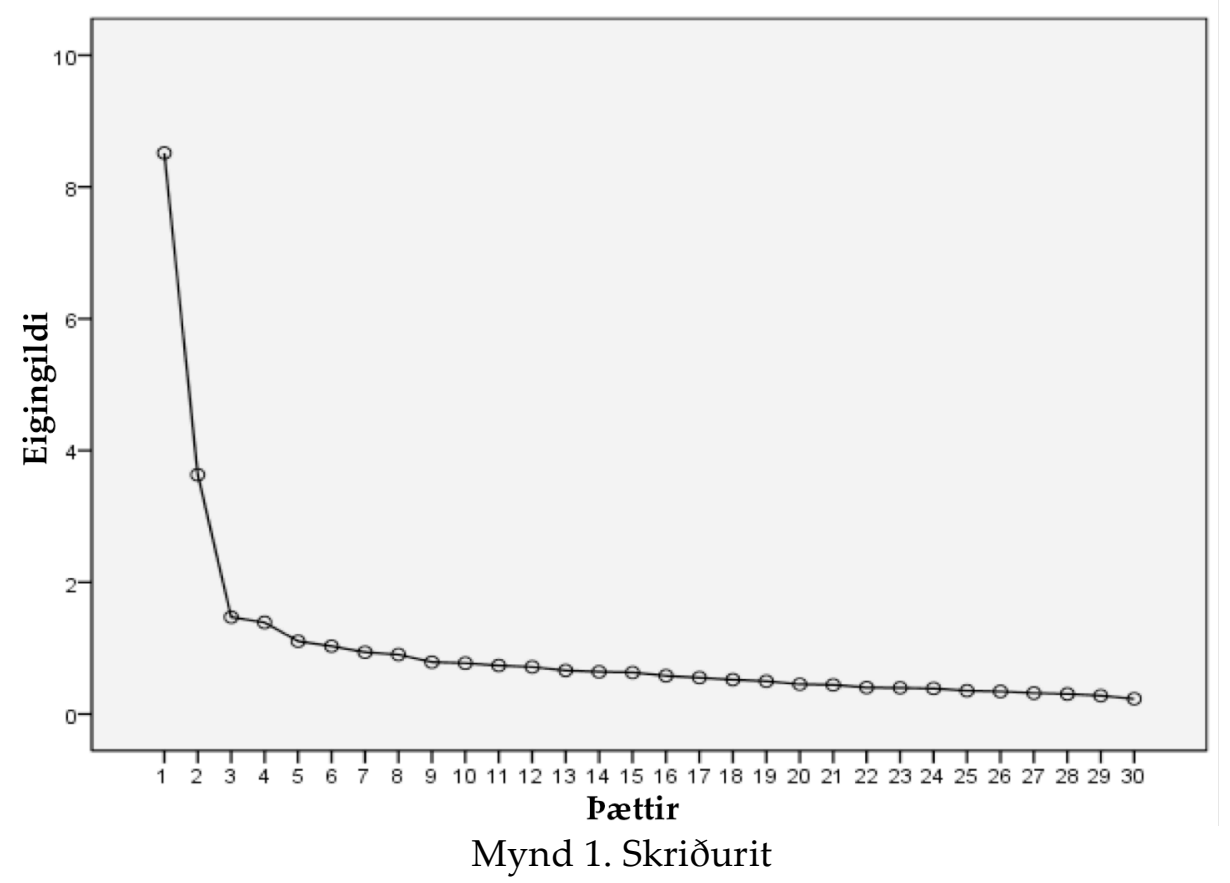

\subsection{Framkvæmd}

Eftir pýðingu spurningalistans var hann forprófaður á nokkrum einstaklingum með раð аð markmiði að kanna hvort spurningarnar væru skýrar og skiljanlegar. Í kjölfarið var listinn fínpússaður og loks settur upp með rafrænum hætti í Google Docs. Spurningalistinn var sendur á hóp fólks sem valið var eftir hentugleika par sem óskað var eftir að fólk tæki pátt og jafnframt að pað sendi listann áfram á aðra sem kynnu að hafa áhuga á að svara. Söfnun gagna fór fram frá desember 2010 til mars 2011.

\section{Niðurstöður}

Páttagreining (principal component analysis) var framkvæmd á breytum gagnasafnsins með hornréttum snúningi (varimax orthogonal rotation). Kaiser-Meyer-Olkin próf staðfesti að úrtakið væri nægjanlega stórt fyrir greininguna $(\mathrm{KMO}=0,918)$ og Bartletts prófið (Bartlett's test of sphericity) var marktækt $\left(\chi^{2}(435)=5903,088 ; p<\right.$ 0,0001) sem gaf til kynna að fylgni væri til staðar milli breyta í gagnasafninu.

Ekki var fullt samræmi í fjölda pátta eftir eigingildum (eigenvalues) og skriðuriti (scree plot). Sex pættir voru með eigingildi yfir 1 og samsetning peirra skýrði 57,2\% af dreifingunni. Aðeins prjár breytur hlóðu hæst á fimmta páttinn og aðeins ein breyta hlóð hæst á sjötta páttinn. Rannsakanda pótti skriðuritið (sjá mynd 1) benda til pess að pættirnir væru fjórir. Sá fjöldi pátta pótti jafnframt eðlilegri pegar horft var til breytanna og pví var kölluð fram fjögurra pátta lausn. Samsetning peirra pátta skýrði 50\% af dreifingunni.

Í töflu 2 má sjá pættina og hleðslu hverrar breytu. Par má jafnframt sjá innri áreiðanleika páttanna sem mældur var með Cronbachs alfa $(\alpha)$. Innri áreiðanleiki var mjög góður fyrir fyrstu prjá pættina, en ekki jafn góður fyrir páttinn Skemmtanagildi, en pað skýrist að öllum líkindum af pví að sá páttur byggir á færri breytum en hinir 
Tafla 2. Skipting breytanna í pætti

\begin{tabular}{|c|c|c|c|c|}
\hline & $\begin{array}{l}\text { Áhrif á samfélag } \\
\text { og neyslu }\end{array}$ & $\begin{array}{l}\text { Upplýsingagildi } \\
\text { og gagnsemi }\end{array}$ & $\begin{array}{l}\text { Sjálfsmynd og } \\
\text { samanburður }\end{array}$ & Skemmtanagildi \\
\hline $\begin{array}{l}\text { Vegna auglýsinga kaupir fólk mikið af hlutum sem pað } \\
\text { parf í rauninni ekki á að halda }\end{array}$ & 0,812 & & & \\
\hline $\begin{array}{l}\text { Auglýsingar leiða til pess að samfélagið byggist meira á } \\
\text { efnishyggju par sem fólk einblínir um of á að kaupa og } \\
\text { eignast hluti }\end{array}$ & 0,767 & & & \\
\hline $\begin{array}{l}\text { Auglýsingar leiða til pess að fólk kaupir vörur sem pað } \\
\text { hefur ekki efni á, einungis til að sýna sig. }\end{array}$ & 0,760 & & & \\
\hline Auglýsingar leiða til óæskilegra gilda í okkar samfélagi & 0,742 & & & \\
\hline $\begin{array}{l}\text { Flestar auglýsingar raska gildum ungu kynslóðarinnar } \\
\text { okkar }\end{array}$ & 0,682 & & & \\
\hline Auglýsingar láta fólk lifa í ímynduðum heimi & 0,681 & & & \\
\hline $\begin{array}{l}\text { Auglýsingar sannfæra fólk um að kaupa eitthvað sem } \\
\text { pað ætti ekki að kaupa }\end{array}$ & 0,614 & & & \\
\hline $\begin{array}{l}\text { Sumar vörur og pjónusta sem er kynnt í auglýsingum } \\
\text { eru slæmar fyrir samfélagið }\end{array}$ & 0,584 & & & \\
\hline $\begin{array}{l}\text { Flestar auglýsingar gera lítið úr greind hins almenna } \\
\text { neytanda }\end{array}$ & 0,551 & & & \\
\hline Auglýsingar eru almennt blekkjandi & 0,537 & & & \\
\hline Рað er of mikil kynferðisleg tenging í auglýsingum í dag & 0,527 & & & \\
\hline $\begin{array}{l}\text { Auglýsingar sýna almennt réttu myndina af peirri vöru } \\
\text { sem verið er að auglýsa }\end{array}$ & 0,382 & & & \\
\hline $\begin{array}{l}\text { Auglýsingar gefa neytendum mikilvægar upplýsingar } \\
\text { um pað sem er í boði á hverjum stað }\end{array}$ & & 0,707 & & \\
\hline Auglýsingar eru nauðsynlegar & & 0,698 & & \\
\hline $\begin{array}{l}\text { Auglýsingar hjálpa mér að fylgjast með vörum og } \\
\text { pjónustu sem eru fáanlegar á markaðnum hverju sinni }\end{array}$ & & 0,681 & & \\
\hline Heilt á litið tel ég auglýsingar vera af hinu góða & & 0,686 & & \\
\hline $\begin{array}{l}\text { Auglýsingar stuðla almennt að samkeppni par sem } \\
\text { neytandinn hagnast }\end{array}$ & & 0,593 & & \\
\hline Mitt almenna álit á auglýsingum er neikvætt & & 0,558 & & \\
\hline Auglýsingar eru að mestu leyti sóun á fjármagni & & 0,523 & & \\
\hline $\begin{array}{l}\text { Auglýsingar segja mér hvaða vörumerki hafa pá } \\
\text { eiginleika sem ég er að leita eftir }\end{array}$ & & 0,502 & & \\
\hline Almennt hjálpa auglýsingar efnahag pjóđarinnar & & 0,484 & & \\
\hline Almennt leiða auglýsingar til pess að verð lækkar & & 0,484 & & \\
\hline $\begin{array}{l}\text { Auglýsingar gera pað að verkum að pað koma betri } \\
\text { vörur á markað fyrir almenning }\end{array}$ & & 0,437 & & \\
\hline $\begin{array}{l}\text { Auglýsingar hjálpa mér að átta mig á hvaða vörur } \\
\text { endurspegla hvers konar manneskja ég er }\end{array}$ & & & 0,761 & \\
\hline $\begin{array}{l}\text { Með auglýsingum læri ég bæði um tísku og hvað eigi að } \\
\text { kaupa til að ganga í augun á öðrum }\end{array}$ & & & 0,721 & \\
\hline $\begin{array}{l}\text { Auglýsingar segja mér hvað fólk sem er með svipaðan } \\
\text { lífsstíl og ég er að kaupa og nota }\end{array}$ & & & 0,718 & \\
\hline $\begin{array}{l}\text { Auglýsingar hjálpa til við að hækka viðmið okkar um } \\
\text { lífskjör }\end{array}$ & & & 0,460 & \\
\hline $\begin{array}{l}\text { Stundum eru auglýsingar jafnvel skemmtilegri en annað } \\
\text { fjölmiðlaefni }\end{array}$ & & & & 0,752 \\
\hline Auglýsingar eru oft fyndnar og skemmtilegar & & & & 0,713 \\
\hline $\begin{array}{l}\text { Stundum finnst mér gaman að hugsa um pað sem ég sá, } \\
\text { heyrði eða las í auglýsingum }\end{array}$ & & & & 0,616 \\
\hline Innri áreiðanleiki $(\alpha)$ & 0,888 & 0,857 & 0,704 & 0,642 \\
\hline
\end{tabular}


Tafla 3. Skýringarmáttur pátttanna á almennt viðhorf til auglýsinga

\begin{tabular}{|c|c|c|c|c|c|c|}
\hline & $\begin{array}{l}\text { Óst } \\
\text { hall } \\
\text { B }\end{array}$ & $\begin{array}{l}\text { taðlaðir } \\
\text { astuðlar } \\
\text { Staðalvilla }\end{array}$ & $\begin{array}{c}\text { Staðlaðir } \\
\text { hallastuðlar } \\
\beta\end{array}$ & $\begin{array}{r}95 \% \text { vikmi } \\
\text { Neðri mörk }\end{array}$ & $\begin{array}{l}\text { örk fyrir B } \\
\text { Efri mörk }\end{array}$ & $t$ \\
\hline Fasti & 1,079 & 0,263 & & 0,563 & 1,596 & \\
\hline Áhrif á samfélag og neyslu & $-0,254$ & 0,045 & $-0,202$ & $-0,343$ & $-0,165$ & $t(483)=-5,60 ; p<0,00$ \\
\hline Upplýsingagildi og gagnsemi & 0,770 & 0,053 & 0,569 & 0,667 & 0,874 & $t(483)=14,64 ; p<0,0($ \\
\hline Sjálfsmynd og samanburður & $-0,041$ & 0,038 & $-0,034$ & $-0,115$ & 0,034 & $t(483)=-1,08 ; p=0,28$ \\
\hline Skemmtanagildi & 0,214 & 0,032 & 0,206 & 0,151 & 0,277 & $t(483)=6,69 ; p<0,00]$ \\
\hline
\end{tabular}

pættirnir auk pess sem smekkur fólks kann að vera breytilegri á pessu sviði.

pættirnir voru settir saman pannig að breyturnar höfðu allar jafnt vægi innan páttanna. Í kjölfarið var framkvæmd aðhvarfsgreining til að athuga hversu stóran hluta af almennu viðhorfi fólks til auglýsinga pættirnir skýrðu. Jafnframt var markmiðið með aðhvarfsgreiningunni að kanna hvaða páttur hafði mestan skýringarmátt á hið almenna viðhorf.

Athugað var hvort gögnin uppfylltu forsendur aðhvarfsgreiningar. Leifin sýndi að ekki var ástæða til að ætla að frávillingar (outliers) væru í gögnunum par sem 4,7\% af gildum stöðluðu leifarinnar voru hærri en tölugildið 2 og aðeins 0,2\% voru hærri en tölugildið 3. Вæði Kolmogorov-Smirnov prófið $(p=0,961)$ og normalritið fyrir leifina (Normal Q-Q plot of Unstandardized Residual) sýndu að villuliðir voru normaldreifðir.

Aðhvarfsgreiningin leiddi í ljós að heildaráhrif líkansins voru marktæk $(F(4,483)$ = 206,25; $p<0,001)$ og að dreifing páttanna skýrði samanlagt 63,1\% af dreifingunni í almennu viðhorfi fólks til auglýsinga.

Pættirnir Áhrif á samfélag og neyslu, Upplýsingagildi og gagnsemi og Skemmtanagildi skýrðu allir almennt viðhorf fólks til auglýsinga. Hins vegar leiddu niðurstöðurnar í ljós að pátturinn Sjálfsmynd og samanburður hafði ekki útskýringarmátt á viðhorfið.

Út frá stöðluðu hallastuðlunum í töflu 3 má sjá að pátturinn Upplýsingagildi og gagnsemi vegur pyngst í pví að skýra viðhorf fólks til auglýsinga og að sá páttur hefur jákvæð áhrif á viðhorfið. Skemmtanagildi hefur jafnframt jákvæðan skýringarmátt á viðhorfið, en pátturinn Áhrif á samfélag og neyslu hefur neikvæðan skýringarmátt. Eins og sést í töflu 3 eru vikmörkin lítil.

Í töflu 4 má m.a. sjá meðalgildi svara við hverjum pætti og mat pátttakenda á almennu viðhorfi til auglýsinga. Fullyrðingarnar í pættinum Áhrif á samfélag og neyslu hafa neikvæða skírskotun og pví er lægra gildi í raun jákvæðara en hærra gildi í peim pætti. Fullyrðingarnar í hinum páttunum premur hafa jákvæða skírskotun og pví er hærra gildi í peim páttum jákvæðara en lægra gildi. Einni breytu í pættinum Áhrif á samfélag og neyslu og tveimur breytum í pættinum Upplýsingagildi og gagnsemi var snúið við til að pær samræmdust öðrum fullyrðingum í sama pætti.

Ekki reyndist munur á almennu viðhorfi kynjanna til auglýsinga $(p>0,05)$ en nokkur munur var eftir aldri $(F(4,543)=3,041 ; p<0,05)$ par sem pátttakendur í elsta hópnum voru nokkuð neikvæðari í garð auglýsinga en pátttakendur í yngsta hópnum. Peir sem starfa (eða hafa starfað) við auglýsingar hafa almennt jákvæðara viðhorf til auglýsinga en aðrir $(t(545)=-2,291 ; p<0,05)$, pó að munurinn á viðhorfi hópanna sé ekki ýkja mikill (Mstarfa viơ auglýsingar =3,53; MHafa ekki starfað viõ auglýsingar = 3,28). 
Tafla 4. Grunnupplýsingar um sérhvern pátt og almennt viðhorf til auglýsinga

\begin{tabular}{lccc}
\hline & M & sf & N \\
\hline Áhrif á samfélag og neyslu & 3,33 & 0,741 & 517 \\
Upplýsingagildi og gagnsemi & 3,22 & 0,685 & 525 \\
Áhrif á sjálfsmynd og samanburð & 2,29 & 0,807 & 535 \\
Skemmtanagildi & 3,29 & 0,897 & 536 \\
Almennt viðhorf & 3,32 & 0,930 & 548 \\
\hline
\end{tabular}

Í töflu 5 hafa verið teknar saman helstu upplýsingar um hverja breytu í pættinum Upplýsingagildi og gagnsemi, en sá páttur reyndist skýra mest af breytileikanum í almennu viðhorfi fólks til auglýsinga. Líkt og má sjá eru flest meðalgildin nokkuð nálægt miðju.

Almennt hallast fólk að pví að auglýsingar séu nauðsynlegar og veiti mikilvægar upplýsingar um pær vörur sem fáanlegar eru á markaðnum og hvað sé í boði á hverjum stað. Fólk virðist ekki telja auglýsingar sérstaklega neikvæðar og hallast fremur að pví að pær séu af hinu góða. Almennt virðist fólk ekki telja að auglýsingar hafi áhrif á efnahag pjóðarinnar eða samkeppni. Раð hallast fremur að pví að auglýsingar leiði hvorki til pess að verð lækki né að pað komi betri vörur á markað.

Ekki reyndist munur á viðhorfum kynjanna til breytanna í pessum pætti $(p>$ 0,05), hins vegar reyndist í um helmingi breytanna vera munur á viðhorfum peirra sem starfa (eða hafa starfað) við auglýsingar annars vegar og peirra sem ekki hafa gert pað hins vegar. Um var að ræða breytur merktar a, c, d, g og h í töflu 5. Munurinn var pó í engum tilfellum verulegur, en var ávallt pannig að peir sem starfa (eða hafa starfað) við auglýsingar höfðu jákvæðara viðhorf en aðrir.

Munur reyndist vera á viðhorfum til priggja breyta eftir aldri. Petta voru eftirfarandi breytur; „heilt á litið tel ég auglýsingar vera af hinu góða“ $(F(4,537)=$

Tafla 5. Upplýsingar um breytur í pættinum Upplýsingagildi og gagnsemi

\begin{tabular}{|c|c|c|c|}
\hline & $M$ & sf & $\mathbf{N}$ \\
\hline $\begin{array}{l}\text { Auglýsingar gefa neytendum mikilvægar upplýsingar } \\
\text { am pað sem er í boði á hverjum stað }\end{array}$ & 3,67 & 1,065 & 549 \\
\hline b. Auglýsingar eru nauðsynlegar & 3,79 & 1,039 & 548 \\
\hline $\begin{array}{l}\text { Auglýsingar hjálpa mér að fylgjast með vörum og } \\
\text { pjónustu sem eru fáanlegar á markaðnum hverju sinni }\end{array}$ & 3,79 & 0,893 & 545 \\
\hline d. Heilt á litið tel ég auglýsingar vera af hinu góða & 3,42 & 0,996 & 542 \\
\hline $\begin{array}{l}\text { Auglýsingar stuðla almennt að samkeppni par sem } \\
\text { neytandinn hagnast }\end{array}$ & 2,99 & 1,076 & 543 \\
\hline f. Mitt almenna álit á auglýsingum er neikvætt & 2,47 & 1,167 & 546 \\
\hline g. Auglýsingar eru að mestu leyti sóun á fjármagni & 2,26 & 1,036 & 546 \\
\hline $\begin{array}{l}\text { h. Auglýsingar segja mér hvaða vörumerki hafa pá } \\
\text { eiginleika sem ég er að leita eftir }\end{array}$ & 3,15 & 1,133 & 545 \\
\hline i. Almennt hjálpa auglýsingar efnahag pjóðarinnar & 2,53 & 1,056 & 547 \\
\hline j. Almennt leiða auglýsingar til pess að verð lækkar & 2,35 & 1,119 & 545 \\
\hline $\begin{array}{l}\text { Auglýsingar gera pað að verkum að pað koma betri } \\
\text { vörur á markað fyrir almenning }\end{array}$ & 2,54 & 1,120 & 546 \\
\hline
\end{tabular}


Tafla 6. Upplýsingar um breytur í pættinum Skemmtanagildi

\begin{tabular}{llcc}
\hline & M & sf & N \\
\hline $\begin{array}{l}\text { a. Stundum eru auglýsingar jafnvel skemmtilegri en } \\
\text { annað fjölmiðlaefni }\end{array}$ & 2,94 & 1,269 & 542 \\
b. Auglýsingar eru oft fyndnar og skemmtilegar & 3,66 & 1,025 & 545 \\
\hline $\begin{array}{l}\text { Stundum finnst mér gaman að hugsa um pað sem ég } \\
\text { sá, heyrði eða las í auglýsingum }\end{array}$ & 3,23 & 1,221 & 545 \\
\hline
\end{tabular}

3,352; $p=0,01)$, „mitt almenna álit á auglýsingum er neikvætt“ $(F(4,541)=3,820 ; p=$ $0,005)$ og "auglýsingar eru að mestu leiti sóun á fjármagni“ $(F(4,541)=7,161 ; p<$ 0,001). Eftir pví sem fólk var eldra pá taldi pað auglýsingar síður af hinu góða, álit peirra var almennt neikvæðara og pað taldi auglýsingar frekar sóun á fjármagni.

Í töflu 6 hafa verið teknar saman helstu upplýsingar um hverja breytu í pættinum Skemmtanagildi. Líkt og má sjá eru meðalgildin nokkuð nálægt miðju.

Konum finnst auglýsingar fyndnari og skemmtilegari en körlum $(t(290)=-2,632$; $p<0,05)$, pó að munurinn sé ekki verulegur par á milli (MKarlar $=3,48$; MKonur $=3,74)$. Konur reynast jafnframt líklegri en karlar til að pykja gaman að hugsa um pað sem pær sjá, heyra eða lesa í auglýsingum $(t(534)=-2,016 ; p<0,05$; MKarlar $=3,08$; MKonur $=$ 3,31). Samt sem áður segja karlar fremur en konur að auglýsingar séu jafnvel

Tafla 7. Upplýsingar um breytur í pættinum Áhrif á samfélag og neyslu

\begin{tabular}{|c|c|c|c|}
\hline & M & sf & $\mathbf{N}$ \\
\hline $\begin{array}{l}\text { Vegna auglýsinga kaupir fólk mikið af hlutum sem } \\
\text { a. pað parf í rauninni ekki á að halda }\end{array}$ & 3,64 & 1,119 & 545 \\
\hline $\begin{array}{l}\text { Auglýsingar leiða til pess að samfélagið byggist meira } \\
\text { b. á efnishyggju par sem fólk einblínir um of á að kaupa } \\
\text { og eignast hluti }\end{array}$ & 3,79 & 1,075 & 546 \\
\hline $\begin{array}{l}\text { Auglýsingar leiða til pess að fólk kaupir vörur sem } \\
\text { pað hefur ekki efni á, einungis til að sýna sig }\end{array}$ & 3,27 & 1,162 & 545 \\
\hline $\begin{array}{l}\text { d. Auglýsingar leiða til óæskilegra gilda í okkar } \\
\text { samfélagi }\end{array}$ & 3,24 & 1,109 & 542 \\
\hline $\begin{array}{l}\text { Flestar auglýsingar raska gildum ungu } \\
\text { kynslóðarinnar okkar }\end{array}$ & 3,37 & 1,168 & 544 \\
\hline f. Auglýsingar láta fólk lifa í ímynduðum heimi & 2,85 & 1,213 & 543 \\
\hline $\begin{array}{l}\text { Auglýsingar sannfæra fólk um að kaupa eitthvað sem } \\
\text { pað ætti ekki að kaupa }\end{array}$ & 3,36 & 1,071 & 547 \\
\hline $\begin{array}{l}\text { humar vörur og pjónusta sem er kynnt í auglýsingum } \\
\text { eru afar slæmar fyrir samfélagið }\end{array}$ & 3,50 & 1,070 & 546 \\
\hline $\begin{array}{l}\text { Flestar auglýsingar gera lítið úr greind hins almenna } \\
\text { neytanda }\end{array}$ & 2,72 & 1,063 & 545 \\
\hline j. Auglýsingar eru almennt blekkjandi & 3,22 & 0,968 & 544 \\
\hline $\begin{array}{l}\text { k. Pað er of mikil kynferðisleg tenging í auglýsingum í } \\
\text { dag }\end{array}$ & 3,32 & 1,124 & 546 \\
\hline $\begin{array}{l}\text { A. Auglýsingar sýna almennt réttu myndina af peirri } \\
\text { vöru sem verið er að auglýsa }\end{array}$ & 2,30 & 0,935 & 546 \\
\hline
\end{tabular}


Tafla 8. Afstöðumunur kynjanna innan páttarins Áhrif á samfélag og neyslu

\begin{tabular}{|c|c|c|c|c|c|}
\hline & Kyn & M & sf & $\mathbf{N}$ & t-próf \\
\hline \multirow{2}{*}{$\begin{array}{l}\text { Vegna auglýsinga kaupir fólk mikið af hlutum } \\
\text { sem pað parf í rauninni ekki á að halda }\end{array}$} & Karlar & 3,80 & 1,070 & 168 & \multirow{2}{*}{$t(534)=2,093 ; p<0,05$} \\
\hline & Konur & 3,58 & 1,126 & 368 & \\
\hline \multirow{2}{*}{$\begin{array}{l}\text { Auglýsingar leiða til pess að fólk kaupir vörur } \\
\text { sem pað hefur ekki efni á, einungis til að sýna }\end{array}$} & Karlar & 3,43 & 1,199 & 169 & \multirow{2}{*}{$t(535)=2,229 ; p<0,05$} \\
\hline & Konur & 3,19 & 1,133 & 368 & \\
\hline \multirow{2}{*}{ Auglýsingar láta fólk lifa í ímynduðum heimi } & Karlar & 3,02 & 1,217 & 167 & \multirow{2}{*}{$t(532)=2,274 ; p<0,05$} \\
\hline & Konur & 2,77 & 1,198 & 367 & \\
\hline \multirow{2}{*}{$\begin{array}{l}\text { Sumar vörur og pjónusta sem er kynnt í } \\
\text { auglýsingum eru afar slæmar fyrir samfélagið }\end{array}$} & Karlar & 3,69 & 1,119 & 169 & \multirow{2}{*}{$t(535)=2,733 ; p<0,01$} \\
\hline & Konur & 3,42 & 1,041 & 368 & \\
\hline \multirow{2}{*}{$\begin{array}{l}\text { Flestar auglýsingar gera lítið úr greind hins } \\
\text { almenna neytanda }\end{array}$} & Karlar & 2,89 & 1,120 & 167 & \multirow{2}{*}{$t(534)=2,500 ; p=0,01$} \\
\hline & Konur & 2,64 & 1,033 & 369 & \\
\hline \multirow{2}{*}{$\begin{array}{l}\text { Pað er of mikil kynferðisleg tenging í } \\
\text { auglýsingum í dag }\end{array}$} & Karlar & 3,10 & 1,203 & 169 & \multirow{2}{*}{$t(535)=-3,041 ; p<0,01$} \\
\hline & Konur & 3,45 & 1,243 & 368 & \\
\hline
\end{tabular}

skemmtilegri en annað fjölmiðlaefni $(t(531)=2,992 ; p<0,05 ;$ MKarlar $=3,18$; MKonur $=$ 2,83), sem virðist stangast nokkuð á við viðhorf kynjanna í hinum breytum pessa páttar. Í öllum tilvikum er munurinn pað lítill og staðalfrávikið í svörum pað hátt að varast ber að draga of miklar ályktanir um mun á viðhorfum kynjanna til skemmtanagildis auglýsinga.

Yngra fólk segir frekar en eldra að pví finnist stundum gaman að hugsa um pað sem pað sér, heyrir eða les í auglýsingum $(F(4,540)=5,878 ; p<0,001)$. Pannig reyndust peir sem voru 25 ára og yngri jákvæðari hvað pennan pátt varðar en bæði peir sem tilheyra aldurshópnum 46 ára til 55 ára og peir sem tilheyra aldurshópnum 56 ára og eldri. Jafnframt reyndust peir sem tilheyra aldurshópnum 26 ára til 35 ára jákvæðari en peir sem tilheyra aldurshópnum 56 ára og eldri. Töluverður munur var á yngsta $\left(\mathrm{M}_{25}\right.$ ára og yngri $\left.=3,52\right)$ og elsta hópnum $\left(\mathrm{M}_{56}\right.$ ára og eldri $\left.=2,68\right)$.

Í töflu 7 hafa verið teknar saman helstu upplýsingar um hverja breytu í pættinum Áhrif á samfélag og neyslu. Líkt og má sjá eru flest meðalgildin nokkuð nálægt miðju.

Pátttakendur telja almennt að auglýsingar hafi áhrif á neyslu fólks. Margir telja pær leiða til pess að fólk kaupi mikið af hlutum sem pað parf ekki á að halda og ýti undir efnishyggju í samfélaginu. Almennt virðast pátttakendur efast um að auglýsingar gefi rétta mynd af pví sem verið er að auglýsa og telja pær jafnvel blekkjandi, prátt fyrir að sú skoðun sé ekki afgerandi.

Í helmingi breytanna reyndist vera munur á afstöðu kynjanna. Í töflu 8 er pessi munur dreginn fram. Eins og sjá má er munurinn yfirleitt ekki mjög mikill, en ólíkust er afstaða kynjanna til pess hvort of mikil kynferðisleg tenging sé í auglýsingum. Konur telja svo vera fremur en karlar, pó að meðalgildið hjá báðum kynjum sé fremur nálægt miðju.

Pegar afstaða fólks til breyta í pættinum Áhrif á samfélag og neyslu er skoðuð út frá pví hvort fólk starfar (eða hefur starfað) við auglýsingar kemur í ljós að í tveimur tilfellum reyndist munur á afstöðunni. Peir sem starfa (eða hafa starfað) við auglýsingar telja síður en aðrir að auglýsingar séu blekkjandi $(t(541)=2,685 ; p<0,01)$, en munurinn er pó ekki afgerandi (Mstarfa við auglýsingar = 2,97; MHafa ekki starfað við auglýsingar = 3,27). Раð vekur í raun athygli að meðalgildið skuli ekki vera nokkuð lægra hjá peim sem hafa starfað við auglýsingar ef gengið er út frá pví að fólk sem komið hefur að auglýsingum vinni af heilindum og sé ekki að reyna að blekkja neytendur. Pessu náskylt reyndist vera munur á afstöðu hópanna til pess hvort auglýsingar sýni rétta 
Tafla 9. Upplýsingar um breytur í pættinum Áhrif á sjálfsmynd og samanburð

\begin{tabular}{llccc}
\hline & M & sf & N \\
\hline a. $\begin{array}{l}\text { Auglýsingar hjálpa mér að átta mig á hvaða vörur } \\
\text { endurspegla hvers konar manneskja ég er }\end{array}$ & 1,69 & 0,884 & 546 \\
$\begin{array}{l}\text { b. Með auglýsingum læri ég bæði um tísku og hvað eigi } \\
\text { að kaupa til að ganga í augun á öðrum }\end{array}$ & 2,19 & 1,131 & 543 \\
\hline $\begin{array}{l}\text { Auglýsingar segja mér hvað fólk sem er með svipaðan } \\
\text { lífsstíl og ég er að kaupa og nota }\end{array}$ & 2,44 & 1,134 & 547 \\
\hline $\begin{array}{l}\text { Auglýsingar hjálpa til við að hækka viðmið okkar um } \\
\text { lífskjör }\end{array}$ & 2,81 & 1,253 & 543 \\
\hline
\end{tabular}

mynd af pví sem verið er að auglýsa $(t(543)=-3,041 ; p<0,005)$. Peir sem ekki hafa starfað við auglýsingar telja síður svo vera (Mstarfa viơ auglýsingar = 2,57; MHafa ekki starfað við̌ auglýsingar $=2,24)$, en hér er líkt og áđur ekki um veigamikinn mun að ræða og athyglisvert að meðalgildið skuli ekki vera hærra hjá peim sem starfa við auglýsingar, ef gengið er út frá pví að fólk á pessum starfsvettvangi leggi sig fram um að sýna neytendum rétta mynd.

Pegar litið var til aldurs pátttakenda reyndist vera munur á viðhorfum í meira en helmingi tilfella. Um var að ræða breytur sem merktar eru b, c, d, e, f, i og k í töflu 7. Í öllum tilvikum töldu peir sem eldri eru áhrif auglýsinga á samfélag og neyslu neikvæðari heldur en peir sem yngri eru. Eftir pví sem fólk var eldra taldi pað auglýsingar t.d. frekar leiða til pess að samfélagið byggðist á efnishyggju, að pær leiddu til óæskilegra gilda, röskuðu gildum ungu kynslóðarinnar eða létu fólk lifa í ímynduðum heimi.

Í töflu 9 hafa verið teknar saman helstu upplýsingar um hverja breytu í pættinum Áhrif á sjálfsmynd og samanburd. Líkt og sjá má á meðalgildunum voru pátttakendur alla jafna töluvert ósammála fullyrðingunum fjórum í pættinum Áhrif á sjálfsmynd og samanburð. Hvergi reyndist vera munur á afstöðu fólks til pessara breyta pegar pátttakendum var skipt í hópa eftir lýðfræðibreytum $(p>0,05)$.

\section{Umræða}

Sá spurningalisti sem notaður var við rannsóknina samanstendur af fjórum páttum; (1) Áhrif á samfélag og neyslu, (2) Upplýsingagildi og gagnsemi, (3) Áhrif á sjálfsmynd og samanburð og (4) Skemmtanagildi. Töluverður samhljómur var á milli peirra pátta sem komu fram í pessari rannsókn og páttunum í rannsókn Pollay og Mittal (1993), pó að pættirnir hér hafi vissulega verið færri. Sá páttur sem reyndist skýra mest almennt viðhorf fólks til auglýsinga var Upplýsingagildi og gagnsemi, en pættirnir Skemmtanagildi og Áhrif á samfélag og neyslu komu par á eftir.

Ekki er hægt að segja að viðhorf pátttakenda til auglýsinga sé sérstaklega jákvætt, en pað hallast pó fremur í jákvæða átt en neikvæða sem er í samræmi við fyrri rannsóknir (Beard, 2003; Petroviki og Marinov, 2007). Pátttakendur reyndust hafa neikvæðara viðhorf gagnvart auglýsingum eftir pví sem peir voru eldri, sem er í samræmi við rannsókn Shavitt o.fl. (1998). Heilt á litið má pó segja að viðhorfið sé ágætt, pó að verulegt svigrúm sé til að bæta hið almenna viðhorf. 
Niðurstöðurnar sýna að til að bæta viðhorfið er mikilvægast að horfa til pess að auglýsingar gefi gagnlegar upplýsingar, enda er pað sá páttur sem reynist hafa mestan skýringarmátt á viðhorfið. Almennt finnst fólki auglýsingar gefa mikilvægar og gagnlegar upplýsingar um pað sem í boði er á markaðnum. Гаð samræmist niðurstöðum fyrri rannsókna sem hafa sýnt að fólki pykir auglýsingar upplýsandi og að pað sé peirra helsti kostur (Coulter o.fl., 2001; Mehta, 2000; Shavitt o.fl.,1998).

Niðurstöðurnar sýndu að fólk efast um að auglýsingar gefi réttu myndina af pví sem verið er að auglýsa og telja pær jafnvel blekkjandi, prátt fyrir að sú skoðun sé ekki afgerandi. Petta samræmist fjölmörgum fyrri rannsóknum sem hafa sýnt að neytendur eru tortryggnir í garð pess sem kemur fram í auglýsingum (Calfee og Ringold, 1988; Ford o.fl., 1990; Mehta, 2000; Muehling, 1987; Petroviki og Marinov, 2007; Prendergast o.fl., 2009; Shah o.fl., 2011; Shavitt o.fl., 1998).

Pessar niðurstöður eru gagnlegar og gefa auglýsendum verðmætar vísbendingar um hvort almennt megi búast við pví að auglýsingar á hinum íslenska markaði skili árangri. Hið almenna viðhorf fólks til auglýsinga hefur áhrif á mat pess á einstökum auglýsingum (O’Donohoe, 2001), sem síðan er áhrifapáttur á viðhorf til vörumerkisins (Mackenzie og Lutz, 1989) og pess hvort auglýsingar leiði til kaupa (Mehta, 2000). Niðurstöðurnar gefa ekki tilefni til að hafa verulegar áhyggjur af stöðunni á íslenskum auglýsingamarkaði, en pó eru viss atriði sem æskilegt væri að huga að. Meðal pess má nefna að auka trúverðugleika auglýsinga almennt. Til að stuðla að slíku er æskilegt að forðast ýkjur um gæði og kosti pess sem verið er að auglýsa (Ashill og Yavas, 2005). Fremur ætti að draga fram ápreifanlega eiginleika og pegar mögulegt er, að draga fram eiginleika sem neytendur geta sannreynt áður en kaup eiga sér stað (Ashill og Yavas, 2005; Ford o.fl., 1990), enda reyndust upplýsingagildi og gagnsemi auglýsinga mesti skýringapátturinn á hið almenna viðhorf samkvæmt niðurstöðum rannsóknarinnar. Jafnframt parf að huga að trúverðugleika peirra miðla sem notaðir eru til að koma auglýsingum á framfæri, pví að ef neytendur hafa litla trú á miðlinum getur pað leitt til pess að peir telji auglýsingarnar sem í honum birtast ótrúverðugri en ella (Prendergast o.fl., 2009).

\section{Takmarkanir og tillögur að frekari rannsóknum}

Eins og alltaf pegar um hentugleikaúrtak er að ræða ber að horfa á niðurstöðurnar með ákveðinni varfærni. Pátttakendur voru ekki valdir með slembiúrtaki og pví er ekki hægt að gera ráð fyrir að peir endurspegli viðhorf Íslendinga almennt til auglýsinga. Prátt fyrir að aldursdreifing hafi verið sæmileg hefði verið ákjósanlegt að hafa fleiri pátttakendur í eldri aldurshópunum. Jafnframt hefði verið gott að fá jafnari kynjaskiptingu, en konur virðast yfirleitt tilbúnari til að taka pátt í könnunum en karlar og eru oftar en ekki í meirihluta pátttakenda pegar um hentugleikaúrtak er að ræða eins og hér er (sjá t.d. Ashill og Yavas, 2005; Beard, 2003).

Í frekari rannsóknum á viðfangsefninu væri áhugavert að skoða viðhorf íslenskra neytenda til auglýsinga í ólíkum miðlum, pá sér í lagi að kanna mun á viðhorfi til sjónvarpsauglýsinga, auglýsinga á prenti og auglýsinga í netmiðlum. Jafnframt væri áhugavert að kanna sýn auglýsenda eða peirra sem starfa við auglýsingagerð til peirra pátta sem hér voru kannaðir og jafnvel athuga hvort peir geri sér grein fyrir pví hvert hið almenna viðhorf neytenda sé. 


\section{Heimildir}

Andrews, J. C. (1989). The dimensionality of beliefs toward advertising in general. Journal of Advertising, 18(1), 26-35.

Ashill, N. J. og Yavas, U. (2005). Dimensions of advertising attitudes. Congruence between Turkish and New Zealand consumers. Marketing Intelligence E Planning, 23(4), 340-349.

Beard, F. K. (2003). College student attitudes toward advertising's ethical, economic, and social consequences. Journal of Business Ethics, 48(3), 217-228.

Bush, A. J., Smith, R. og Martin, C. (1999). The influence of consumer socialization variables on attitude toward advertising: A comparison of African-American and Caucasians. Journal of Advertising, 28(3), 13-24.

Calfee, J. E. og Ringold, D. J. (1988). Consumer skepticism and advertising regulation: What do the polls show? Advances in Consumer Research, 15(1), 244248.

Calfee, J. E. og Ringold, D. J. (1994). The 70\% majority: Enduring consumer beliefs about advertising. Journal of Public Policy \& Marketing, 13(2), 228-238.

Carrigan, M. og Szmigin, I. (1999). In pursuit of youth: What's wrong with the older market? Marketing Intelligence \& Planning, 17(5), 222-231.

Coulter, R. A., Zaltman, G. og Coulter, K. S. (2001). Interpreting consumer perceptions of advertising: An application of the Zaltman metaphor elicitation technique. Journal of Advertising, 30(4), 1- 21.

Fam, K.-S. (2008). Attributes of likeable television commercials in Asia. Journal of Advertising Research, 48(3), 418-132.

Ford, G. T., Smith, D. B. og Swasy, J. L. (1990). Consumer skepticism of advertising claims: Testing hypotheses from economics of information. Journal of Consumer Research, 16(4), 433-441.

José Martínez, I., Dolores Prieto, M. og Farfán, J. (2006). Childhood and violence in advertising. A current perspective. International Communication Gazette, 68(3), 269-287.

Jozsa, L., Insch, A., Kristjanous, J. og Fam, K.-S.. (2010). Beliefs about advertising in China: Empirical evidence from Hong Kong and Shanghai consumers. Journal of Consumer Marketing, 27(7), 594-603.

MacKenzie, S. B. og Lutz, R. J. (1989). An empirical examination of the structural antecedents of attitude toward the ad in an advertising pretesting context. Journal of Marketing, 53(2), 48-65.

Mehta, A. (2000). Advertising attitudes and advertising effectiveness. Journal of Advertising Research, 40(5), 67-72.

Monk-Turner, E., Kouts, T., Parris, K. og Webb, C. (2007). Gender role stereotyping in advertisements on three radio stations: Does musical genre make a difference? Journal of Gender Studies, 16(2), 173-182.

Muehling, D. D. (1987). An investigation of factors underlying attitude-towardadvertising-in-general. Journal of Advertising, 16(1), 32-40.

Mukherji, J. (2009). Communication patterns, mediation behaviors, and advertising attitudes: A study of Hispanic mothers. Competition Forum, 7(2), 488-495.

O'Donohoe, S. (2001). Living with ambivalence: Attitudes to advertising in postmodern times. Marketing Theory, 1(1), 91-108. 
Petroviki, D. og Marinov, M. (2007). Determinants and dantecedents of general attitudes towards advertising. A study of two EU accession countries. European Journal of Marketing, 41(3/4), 307-326.

Pollay, R. W. og Mittal, B. (1993). Here's the beef: Factors, determinants, and segments in consumer criticism of advertising. Journal of Marketing, 57(3), 99-114.

Prendergast, B., Liu, P og Poon, D. T. Y. (2009). A Hong Kong study of advertising credibility. Journal of Consumer Marketing, 26(5), 320-329.

Shah, M. H., Chen, X. og Chauhan, A. K. (2011). Does consumer believe on advertisers? The evaluation of advertising skepticism in India and China. Asian Scocial Science, 7(3), 26-36.

Shavitt, S. Lowery, P og Haefner, J. (1998). Public attitudes toward advertising: More favorable than you might think. Journal of Advertising Research, 38(4), 7-22.

Usman, M., Ilyas, S., Hussain, M. F. og Quareshi, T. M. (2010). General attitude towards advertising: Cultural influences in Pakistan. International Journal of Marketing Studies, 2(2), 124-133.

Wolin, L. D. og Korgaonkar, P. (2003). Web advertising: Gender differences in beliefs, attitudes and behavior. Internet Research, 13(5), 375-385. 